\title{
Chronic virus infections supress atopy but not asthma in a set of children from a large latin american city: a cross-section study
}

\author{
Rafael V Veiga ${ }^{1,2}$, Sergio S Cunha ${ }^{1,3}$, Vitor CC Dattoli ${ }^{1,2}$, Álvaro C Cruz ${ }^{1,4}$, Phillip J Cooper ${ }^{1,5,6}$, Laura C Rodrigues ${ }^{1,7}$,
} Maurício L Barreto ${ }^{1,8}$ and Neuza M Alcantara-Neves ${ }^{1,2^{*}}$

\begin{abstract}
Background: The prevalence of allergic diseases has increased over recent decades in affluent countries, but remains low in rural populations and some non-affluent countries. An explanation for these trends is that increased exposure to infections may provide protection against the development of allergy. In this work we investigated the association between exposure to viral infections in children living in urban Brazil and the prevalence of atopy and asthma.
\end{abstract}

Methods: School age children living in poor neighborhoods in the city of Salvador were studied. Data on asthma symptoms and relevant risk factors were obtained by questionnaire. Skin prick tests (SPTs) were performed to seven aeroallergens, and specific lgE was measured to four of these. Viral infections were determined by the presence of specific lgG in serum to Herpes simplex (HSV), Herpes zoster (HZV), Epstein-Barr (EBV), and Hepatitis A (HAV) viruses.

Results: A total of 644 (49.7\%) children had at least one allergen-specific lgE $>0.35 \mathrm{kU} / \mathrm{L}$ and 489 (37.7\%) had specific IgE $>0.70 \mathrm{kU} / \mathrm{L}$. A total of 391 (30.2\%) children were skin test positive (SPT+), and 295 (22.8\%) children were asthmatic. The seroprevalence of viral infections was $88.9 \%$ for EBV, 55.4\% for HSV, 45.5\% for VZV and 17.5\% for HAV. Negative associations were observed between SPT+ and HSV (OR $=0.64, \mathrm{Cl}=0.51,0.82)$ and EBV $(\mathrm{OR}=0.63$, $\mathrm{Cl}=0.44,0.89$ infections, but no associations were seen between viral infections and the presence of allergenspecific lgE or asthma.

Conclusion: These data do not support previous data showing a protective effect of HAV against atopy, but did show inverse associations between SPT+ (but not specific lgE+) and infections with HSV and EBV. These findings suggest that different viral infections may protect against SPT+ in different settings and may indicate an immunoregulatory role of such infections on immediate hypersensitivity responses. The data provide no support for a protective effect of viral infections against asthma in this population.

\section{Background}

The prevalence of allergic diseases, such as rhinitis, asthma and eczema has increased in affluent countries over recent decades, and may have increased also in cities of non-affluent countries such as in Latin America [1]. Such temporal trends occurring over a relatively short period of time are unlikely to be explained by

\footnotetext{
* Correspondence: neuza@ufba.br

'SCAALA (Social Change, Asthma and Allergy in Latin America) Research Program

Full list of author information is available at the end of the article
}

changes in genetic susceptibility and are most likely explained by changes in environmental exposures such as those associated with the adoption of a modern or 'westernized' lifestyle [2].

Strachan [3] observed that children lower in the birth order had a reduced prevalence of hay fever and interpreted this observation in terms of younger children being more highly exposed to infections in early life through contact with their older siblings. This interpretation, coined the hygiene hypothesis, and has been widely promoted to explain the temporal trends in allergic disease prevalence.

\section{Ciomed Central}


Allergic diseases are complex inflammatory disorders with significant genetic components $[4,5]$ and are strongly influenced by environmental factors [6-8]. Allergic inflammation is considered to develop following immediate hypersensitivity reactions to environmental antigens which leads to the development of an immune response characterized by high levels of IgE and increased numbers of eosinophils and mast cell cells, and a Th2 immune profile [9]. In the early $1990 \mathrm{~s}$, with the discoveries of Th1 and Th2 lymphocyte populations in animal models and the realization that infection with bacteria and viruses induce the innate immune system to release Th1 cytokines, a possible biological explanation for the hygiene hypothesis emerged. When born, a child has a predominantly Th2 immune response, requiring the presence of infections to stimulate the Th1 system in early childhood and achieve a balance between Th1 and Th2 responses to prevent a Th2 bias that favor Th2 allergic diseases [10]. Although humans may respond differently to infections, there is epidemiological evidence for inverse associations between infections and allergic diseases that support this hypothesis. Such infections include hepatitis A [11], Herpes simplex [12] and Epstein-Barr viruses [13], viral lower respiratory tract infections [14], and Mycobacterium tuberculosis infection [15].

To test the hypothesis that childhood viral infections protect against allergy and asthma, we compared the seroprevalence of common childhood viral infections between children with and without atopy and asthma living in poor neighborhoods in a Brazilian city.

\section{Methods}

\section{Population and study design}

The study was conducted in a cohort of 1,445 children living in poor neighborhoods of Salvador, a city with a population of 2.5 million with a high prevalence of asthma [16]. This cohort of children aged 4-13 years was derived from an earlier study on the impact of sanitation on childhood diarrhea conducted in 24 sentinel areas in Salvador, and the study design is described in detail elsewhere [17]. A questionnaire to collect information on risk factors, demographic factors, and key allergic symptoms [ISAAC-based] was administered to the child's parent or guardian in 2005. The children underwent skin prick tests (SPTs) to seven aeroallergens. Blood samples were collected and the sera were stored at $-20^{\circ} \mathrm{C}$ and used to measure IgG to relevant pathogens and allergen-specific IgE (sIgE).

This study was approved by the Ethics Committee for Research of the Instituto de Saúde Coletiva da Universidade Federal da Bahia and CONEP (National Council of Ethics in Research); written consent to participate in the work, containing information about history of allergies and their risk factors, was obtained from parents or guardians.

\section{Asthma definition}

Children were classified as having asthma if parents reported wheezing in the previous 12 months and at least one of the following: (i) diagnosis of asthma ever; (ii) wheezing with exercise in the last 12 months; (iii) 4 episodes wheezing in the last 12 months; (iv) waking up at night because of wheezing in the last 12 months.

\section{Skin prick test}

The SPT was carried out using ALK-Abello reagents (São Paulo, Brazil) for the following allergens identified as regionally relevant by previous unpublished work: Dermatophagoides pteronyssinus, Blomia tropicalis, Blattella germanica, Periplaneta americana, dog and cat epithelia, and a mixture of fungi (Aspergillus amstelodami, A. fumigatus, A. niger, A. terrus, Penicillium brevicompactum, $P$. expansum, $P$. notatum, $P$. roqueforti, Cladosporium fulvum, and $C$. herbarum). Positive and negative controls were $10 \mathrm{mg} / \mathrm{mL}$ histamine and saline, respectively. Allergens and controls were applied to the right forearm. After 15 minutes, the reaction was measured and was considered positive when the mean wheal diameter was at least $3 \mathrm{~mm}$ greater than the negative control. Children positive for at least one of the studied allergens were classified as SPT positive. Children who used anti-allergic drugs were excluded from the study.

\section{Measurements of anti-aeroallergen IgE antibodies}

The presence of specific IgE antibodies to D. pteronyssinus, B. tropicalis, P. americana and B. germanica in the children's sera was determined using the lmmunoCap system (Phadia Uppsala, Sweden). These antigens were chosen because they were the most frequently observed to cause SPT reactivity in these children. The results, expressed in $\mathrm{kU} / \mathrm{L}$ (lower limit corresponding to $2.4 \mathrm{ng} /$ $\mathrm{ml}$ ), were obtained by a standard curve produced by serial dilutions of human IgE against a standard serum IgE provided by the World Health Organization (WHO standard 75/502). The IgE cut preconized by the manufacturer is $0.35 \mathrm{kU} / \mathrm{L}$. However cross-reactivities between allergen reactive IgEs and many organisms, including helminthes have being reported at this cut-off [18]. That is why we decided to use both $\operatorname{IgE} \geq 0.35 \mathrm{kU} /$ $\mathrm{L}$ and $\geq 0.70 \mathrm{kU} / \mathrm{L}$ cut-offs. Children were considered positive when they had values greater than these cut-off points for at least one of the studied allergens.

\section{Detection of viral lgG}

The presence of serum antibodies in the children's sera against herpes simplex (HSV), herpes zoster (HZV) and Epstein-Barr (EBV) viruses was determined by ELISA 
assay using kits from Diamedix (Miami, Florida, USA), following the manufacturer's instructions. For the hepatitis A virus (HAV), kits from ADALTIS were used (Toronto, Canada). The cut-off points were determined by the index derived from the relationship: absorbance of sample/calibrator absorbance (solution containing human serum or defibrinated plasma weakly reactive for antibodies against the respective virus and $0.1 \%$ sodium azide). Indices greater than 1.1 were considered positive, less than 0.9 were considered negative and between 1.1 and 0.9 were considered indeterminate, and these children were excluded from the analysis.

\section{Statistical analysis}

Analyses were done with children with no missing data for the variables analyzed, and comparisons were made between the studied and the excluded groups using the chi-square test or the $t$-test (two-tailed). We assessed the association between the presence of serum antibodies for the 4 viruses (main exposures) and specific serum IgE, skin reactivity for environmental allergens and the presence of asthma (outcome variables). Potential confounders for the association between virus infections and outcomes were: maternal education, presence of a sewage disposal system, frequency of changing bed linen, number of siblings, presence of cat and dog in the house, smoking parents, presence of mold or dampness in the walls of the house (by inspection) and if the child had attended daycare. Although we collected data about children vaccination, none was vaccinated for the viruses used in this analysis, and then, this variable was removed from the study.

The associations between exposure outcomes (IgE, SPT and asthma) were assessed using logistic regression to estimate odds ratios (OR) and 95\% confidence intervals (CIs). Variables were entered individually in multivariate models and if the variable was non-significant $(P>0.05)$ it was removed, but if significant, was kept in the analysis. Only significant variables were kept in the models. Gender and age were considered a priori confounders and kept in all models. Analysis on multiplicative interactions between each infection and gender in relation to all outcomes was done, and co-linearity between viral infections was also assessed. Finally, we tested for the effects of clustering by neighborhood, using random effects models, but because such adjustment did not alter effects, results without adjustment for clustering were provided. Analyses were performed using SPSS (Release 16.0, SPSS, Inc) and multinomial (polytomous) logistic regression analyses using STATA (Release 9.0, Stata Corp).

\section{Results}

\section{Characteristics of study population}

Of the 1,445 children enrolled in the cohort, $89.7 \%$ (1296) with complete data were included in the present analysis. No significant differences were found between the 149 excluded and the 1,296 studied included within respect to relevant baseline variables. The mean age of the children was 7.2 years (standard deviation $(\mathrm{SD}=$ 1.7), and $53.8 \%$ were male. A history of parental asthma was present in $13.3 \%$ of the children, and $27.4 \%$ had at least one smoker at home. The results showed that $44.2 \%$ of the children had the bed linen changed more than once a week, $82.8 \%$ had a sewage system in their home, $64.9 \%$ had mold and moisture in the walls of their houses, and $39.6 \%$ lived with dogs and $17.7 \%$ with cats. Only 386 (29.8\%) of the children had mothers who had completed secondary education. Children had, on average, 1.8 (SD = 1.8) siblings. Only 209 (16\%) children had attended daycare. Seropositivity for the studied viruses was $88.9 \%$ for EBV, $55.4 \%$ for HSV, $45.5 \%$ for VZV and $17.5 \%$ for HAV. Seroprevalence increased with age, and only herpes simplex was found to be associated with gender (greater in girls; data not shown). The prevalence of IgE-sensitization using the two cut-offs were: $\operatorname{IgE}>0.35 \mathrm{kU} / \mathrm{L}$, and $\mathrm{IgE}>0.70 \mathrm{kU} / \mathrm{L}, 49.7 \%$ and $37.7 \%$, respectively. SPT positivity for at least one of the studied allergens was present in $30.2 \%$ of the children, and the prevalence of asthma was $22.8 \%$ (Table 1 ).

All studied viral infections were associated with each other (data not shown); however, comparing the logistic models using all infections in the same model or with each infection in separate models, there was no significant change in the ORs for the 3 infection-outcome associations, so we included all infections in the same model. There was not important heterogeneity of effect for any of the variables studied using multiplicative interaction terms between each infection and gender in relation to the outcomes (Data not shown).

\section{Associations of viral infections with anti-lgE antibodies to environmental allergens}

Among potential risk factors, only gender was significantly associated with specific IgE using a cut-off of IgE $\geq 0.70$ (boys > girls, Table 1 ). No association was found between viral infections and the presence of specific IgE to environmental allergens using either cut-off $(\geq 0.35$ and $\geq 0.70$ ) (Table 1 and 2).

\section{Associations of viral infections with skin prick test (SPT) for environmental allergens}

Only gender was significantly associated with SPT, being more frequent in boys. A negative association of SPT with both HSV and EBV infections were observed (unadjusted, $\mathrm{OR}=0.64 ; \mathrm{CI}=0.51-0.82$ and $\mathrm{OR}=0.63 ; \mathrm{CI}=$ 0.44-0.89, respectively; adjusted for age and sex, $\mathrm{OR}=$ 0.66 ; $\mathrm{CI}=0.51-0.84$ and adjusted $\mathrm{OR}=0.69 ; \mathrm{CI}=0.48$ 0.99 , respectively). No associations were found between SPT and HAV and VZV infections (Table 1 and 3). 
Table 1 Associations between viral infections with aeroallergen IgE, skin test reactivity (SPT) and asthma

\begin{tabular}{|c|c|c|c|c|c|c|c|}
\hline \multirow{3}{*}{$\begin{array}{l}\text { Variables } \\
\mathrm{N}=1296\end{array}$} & \multirow{3}{*}{$\begin{array}{l}\text { Total population } n=1296 \\
\text { n (\%) }\end{array}$} & \multicolumn{6}{|c|}{ Number and percentage of children positive for the outcomes } \\
\hline & & \multicolumn{2}{|c|}{$\begin{array}{c}\lg E \geq 0.70 \\
n=489(37.7 \%)\end{array}$} & \multicolumn{2}{|c|}{$\begin{array}{c}\text { SPT } \\
\mathrm{n}=391(30.2 \%)\end{array}$} & \multicolumn{2}{|c|}{$\begin{aligned} & \text { Asthma } \\
\mathrm{n}= & 295(22.8 \%)\end{aligned}$} \\
\hline & & n (\%) & p-value & n (\%) & p-value & n (\%) & p-value \\
\hline \multicolumn{8}{|l|}{ Gender } \\
\hline Male & $697(53.8)$ & *306(43.9) & $<0.001$ & $233(33.4)$ & 0.006 & 164(23.5) & 0.477 \\
\hline \multicolumn{8}{|l|}{ Age (years) } \\
\hline $4-6$ & $333(25.7)$ & 123(36.9) & 0.914 & $92(27.6)$ & 0.230 & 113(33.9) & $<0.001$ \\
\hline 6 and 7 & $531(41.0)$ & $200(37.7)$ & & 156(29.4) & & $117(22.0)$ & \\
\hline $7-11$ & $432(33.3)$ & 166(38.4) & & 143(33.1) & & $65(15.0)$ & \\
\hline Parental asthma & 173(13.3) & $57(32.9)$ & 0.163 & $50(28.9)$ & 0.696 & $61(35.3)$ & $<0.001$ \\
\hline \multicolumn{8}{|l|}{ Sibling $n^{\circ}$. } \\
\hline 0 & $241(18.6)$ & $98(40.7)$ & 0.683 & $78(32.4)$ & 0.213 & $54(22.4)$ & 0.936 \\
\hline 1 & $459(35.4)$ & 167(36.4) & & 148(32.2) & & 109(23.7) & \\
\hline 2 & $306(23.6)$ & 118(38.6) & & $91(29.7)$ & & $67(21.9)$ & \\
\hline 3 or more & $290(22.4)$ & 106(36.6) & & $74(25.5)$ & & $65(22.4)$ & \\
\hline \multicolumn{8}{|l|}{ Mother's education } \\
\hline Illiterate & $177(13.7)$ & $74(41.8)$ & 0.616 & $50(28.2)$ & 0.570 & $54(30.5)$ & 0.025 \\
\hline Primary complete & $444(34.3)$ & $160(36.0)$ & & $126(28.4)$ & & 102(23.0) & \\
\hline Secondary incomplete & $289(22.3)$ & 109(37.7) & & $90(31.1)$ & & $66(22.8)$ & \\
\hline Secondary complete & $386(29.8)$ & 146(37.8) & & 125(32.4) & & 73(18.9) & \\
\hline Daycare ever Yes & $208(16.0)$ & $77(37.0)$ & 0.817 & $53(25.5)$ & 0.108 & $61(29.3)$ & 0.014 \\
\hline Smoker at home & $355(27.4)$ & 127(35.8) & 0.372 & $99(27.9)$ & 0.272 & $88(24.8)$ & 0.285 \\
\hline Sewage system Yes & 1073(82.8) & 414(38.6) & 0.165 & $327(30.5)$ & 0.599 & 242(22.6) & 0.694 \\
\hline Change bed linen $1 \times$ week & $573(44.2)$ & 212(37.0) & 0.628 & 173(30.2) & 0.988 & 137(23.9) & 0.381 \\
\hline Cat at home Yes & $230(17.7)$ & $83(36.1)$ & 0.570 & $61(26.5)$ & 0.184 & $66(28.7)$ & 0.018 \\
\hline Dog at home Yes & $513(39.6)$ & 187(36.5) & 0.442 & 147(28.7) & 0.336 & $129(25.1)$ & 0.098 \\
\hline Mold/moisture at home & $841(64.9)$ & 318(37.8) & 0.935 & 253(30.1) & 0.926 & $210(25.0)$ & 0.010 \\
\hline \multicolumn{8}{|l|}{ Seropositivity } \\
\hline Herpes simplex & $712(54.9)$ & $254(35.7)$ & 0.092 & $185(26.0)$ & $<0.001$ & 158(22.2) & 0.588 \\
\hline Varicella zoster & $588(45.4)$ & $216(36.7)$ & 0.500 & 171(29.1) & 0.437 & 132(22.4) & 0.806 \\
\hline Epstein-Barr & $1149(88.7)$ & $423(36.8)$ & 0.057 & $333(29.0)$ & 0.009 & $258(22.5)$ & 0.460 \\
\hline Hepatitis A & $224(17.3)$ & $80(37.7)$ & 0.493 & $65(29.0)$ & 0.680 & $50(22.3)$ & 0.863 \\
\hline
\end{tabular}

*Numbers shown in bold are statistically significant $\left(\mathrm{Chi}^{2}\right.$ test; $\left.\mathrm{p}<0.05\right)$.

\section{Association of viral infections with asthma}

No infection was significantly associated with asthma in either univariate or multivariate analyses. Moisture and mold on the walls and daycare attendance were significantly associated with asthma in univariate but not in multivariate analysis (Tables 1 and 4). No association was found between the viral infections and either atopic or non-atopic asthma using atopic non-asthmatic or non-atopic non-asthmatic children as comparison groups, respectively (Table 5).

\section{Discussion}

In our study, we found no association between the HSV infection and the presence of aerollaergen-specific IgE or asthma; however, a significant negative association was observed with SPT in multivariate analyses, indicating that exposures to this infection may be associated with suppression of immediate hypersensitivity responses. The immune response of allergic diseases is typically $\mathrm{Th} 2$; thus, it is possible that pathogenic or non-pathogenic organisms (or their molecules) that suppress this response can induce protection from allergies. Among the known factors that can suppress a Th2 immune response, one can highlight Th1 and T-regulatory (T-reg) cells stimulators. In vitro studies have shown that HSV DNA can induce tumor necrosis factor (TNF $\alpha$ ) and interleukin (IL)-6, a Th1 immune response, and release interferon (IFN)- $\gamma$ [19]. Matricardi and collaborators [20], studying a North American population, showed that HSV protected against asthma and hay fever. Janson and colleagues [12], studying young adults in Iceland, Sweden and Estonia, showed that HSV was negatively associated with atopy.

Our data showed that EBV was negatively associated with skin reactivity. EBV has a different mechanism of 
Table 2 Logistic regression analyses of association between seropositivity to common viral infections of childhood and the presence of aeroallergen-specific IgEs using cut-offs for specific IgE of $\geq 0.35$ and $\geq 0.70 \mathrm{kU} / \mathrm{L}$

\begin{tabular}{|c|c|c|c|c|c|c|}
\hline \multirow{3}{*}{$\begin{array}{l}\text { Infection by } \\
N=1296\end{array}$} & \multicolumn{3}{|c|}{${ }^{*} \operatorname{slg} \mathrm{E} \geq 0.35(n=644 / 49.7 \%)$} & \multicolumn{3}{|c|}{$\operatorname{slg} E \geq 0.70(n=489 / 37.7 \%)$} \\
\hline & \multicolumn{3}{|c|}{ OR (95\% C.I.) } & \multirow[b]{2}{*}{ n (\%)/N } & \multicolumn{2}{|c|}{ OR (95\% C.I.) } \\
\hline & n (\%)/N & Crude & Adjusted ${ }^{* *}$ & & Crude & Adjusted** \\
\hline \multicolumn{7}{|l|}{ HSV } \\
\hline Negative & 298(51.0)/584 & 1 & 1 & $235(40.2) / 584$ & 1 & 1 \\
\hline Positive & $346(48.6) / 712$ & $\begin{array}{c}0.91 \\
(0.73 ; 1.13)\end{array}$ & $\begin{array}{c}0.94 \\
(0.75 ; 1.18)\end{array}$ & 254(35.7)/712 & $\begin{array}{c}0.82 \\
(0.66 ; 1.03)\end{array}$ & $\begin{array}{c}0.88 \\
(0.69 ; 1.11)\end{array}$ \\
\hline \multicolumn{7}{|l|}{ VZV } \\
\hline Negative & $357(50.4) / 708$ & 1 & 1 & 273(38.6)/708 & 1 & 1 \\
\hline Positive & 287(48.8)/588 & $\begin{array}{c}0.94 \\
(0.75 ; 1.17)\end{array}$ & $\begin{array}{c}0.93 \\
(0.74 ; 1.17)\end{array}$ & $216(36.7) / 588$ & $\begin{array}{c}0.93 \\
(0.74 ; 1.16)\end{array}$ & $\begin{array}{c}0.93 \\
(0.74 ; 1.17)\end{array}$ \\
\hline \multicolumn{7}{|l|}{ EBV } \\
\hline Negative & $80(54.4) / 147$ & 1 & 1 & $66(44.9) / 147$ & 1 & 1 \\
\hline Positive & $564(49.1) / 1149$ & $\begin{array}{c}0.81 \\
(0.57 ; 1.14)\end{array}$ & $\begin{array}{c}0.82 \\
(0.58 ; 1.17)\end{array}$ & $423(36.8) / 1149$ & $\begin{array}{c}0.71 \\
(0.51 ; 1.01)\end{array}$ & $\begin{array}{c}0.75 \\
(0.53 ; 1.07)\end{array}$ \\
\hline \multicolumn{7}{|l|}{ HAV } \\
\hline Negative & $531(49.5) / 1072$ & 1 & 1 & $409(38.2) / 1072$ & 1 & 1 \\
\hline Positive & 113(50.4)/224 & $\begin{array}{c}1.04 \\
(0.78 ; 1.38)\end{array}$ & $\begin{array}{c}1.07 \\
(0.80 ; 1.44)\end{array}$ & $80(35.7) / 224$ & $\begin{array}{c}0.90 \\
(0.67 ; 1.22)\end{array}$ & $\begin{array}{c}0.94 \\
(0.69 ; 1.28)\end{array}$ \\
\hline
\end{tabular}

*Aeroallergen-specific IgE; **Adjusted for gender and age.

protection of allergic diseases. It induces T-regs cells as an escape mechanism from the immune system, and although this mechanism has not been well elucidated, it seems to involve an elevation of IL-10 and transforming growth factor (TGF) $-\beta$. Wingate and collaborators [21] and Marshall and collaborators [22] found in the EBV genome a well-preserved sequence homologous to IL-10, which may be influencing this immunomodulation [23].

Table 3 Logistic regression analyses of associations between viral infections and skin prick test reactivity (SPT) for at least one aeroallergen

\begin{tabular}{|c|c|c|c|}
\hline \multirow[t]{3}{*}{$\begin{array}{l}\text { Infection by } \\
\mathrm{N}=1296\end{array}$} & \multicolumn{3}{|c|}{$\begin{array}{c}\text { SPT } \geq 0.3 \mathrm{~mm} \\
\mathrm{n}=391(30.2 \%)\end{array}$} \\
\hline & \multirow[t]{2}{*}{ n (\%)/N } & \multicolumn{2}{|c|}{ OR (95\% C.I.) } \\
\hline & & Crude & Adjusted* \\
\hline \multicolumn{4}{|l|}{ HSV } \\
\hline Negative & $206(35.3) / 584$ & $* * 1$ & 1 \\
\hline Positive & $185(26.0) / 712$ & $0.64(0.51 ; 0.82)$ & $0.66(0.51 ; 0.84)$ \\
\hline \multicolumn{4}{|l|}{ VZV } \\
\hline Negative & $220(31.1) / 708$ & 1 & 1 \\
\hline Positive & $171(29.1) / 588$ & $0.91(0.72 ; 1.15)$ & $0.89(0.70 ; 1.14)$ \\
\hline \multicolumn{4}{|l|}{ EBV } \\
\hline Negative & $58(39.5) / 147$ & 1 & 1 \\
\hline Positive & $333(29.0) / 1149$ & $0.63(0.44 ; 0.89)$ & $0.69(0.48 ; 0.99)$ \\
\hline \multicolumn{4}{|l|}{ HAV } \\
\hline Negative & $326(30.4) / 1072$ & 1 & 1 \\
\hline Positive & $65(29.0) / 224$ & $0.94(0.68 ; 1.28)$ & $1.01(0.73 ; 1.40)$ \\
\hline
\end{tabular}

*Adjusted for gender and age. ${ }^{* * B}$ Bold values are statistically significant $(\mathrm{p}<$ 0.05).
Several studies have reported EBV associated with protection of atopy $[13,24]$.

In relation to $\mathrm{HAV}$ infection, our data, as well as others in the literature $[12,25,26]$ showed no evidence of its association with the study outcomes. In addition to being an indicator of poor hygiene conditions, the HAV can also have an immunoregulatory role in reducing asthma in its hosts. Polymorphism of a receptor (TIM-

Table 4 Logistic regression analyses of associations between viral infections and asthma

\begin{tabular}{|c|c|c|c|}
\hline \multirow{3}{*}{$\begin{array}{l}\text { Infection by } \\
\mathrm{N}=1272\end{array}$} & \multicolumn{3}{|c|}{$\begin{array}{c}\text { Asthma } \\
\mathrm{n}=295(22.8 \%)\end{array}$} \\
\hline & \multirow[t]{2}{*}{ n (\%)/N } & \multicolumn{2}{|c|}{ OR (95\% C.I.) } \\
\hline & & Crude & Adjusted* \\
\hline \multicolumn{4}{|l|}{ HSV } \\
\hline Negative & 137 (23.5)/584 & 1 & 1 \\
\hline Positive & $158(22.2) / 712$ & $0.93(0.72 ; 1.21)$ & $1.02(0.77 ; 1.35)$ \\
\hline \multicolumn{4}{|l|}{ VZV } \\
\hline Negative & $163(23.0) / 708$ & 1 & 1 \\
\hline Positive & $132(22.4) / 588$ & $0.97(0.75 ; 1.26)$ & $1.09(0.82 ; 1.43)$ \\
\hline \multicolumn{4}{|l|}{ EBV } \\
\hline Negative & $37(25.2) / 147$ & 1 & 1 \\
\hline Positive & $258(22.5) / 1149$ & $0.86(0.58 ; 1.28)$ & $0.81(0.53 ; 1.23)$ \\
\hline \multicolumn{4}{|l|}{ HAV } \\
\hline Negative & $245(22.9) / 1072$ & 1 & 1 \\
\hline Positive & $50(22.3) / 224$ & $0.97(0.69 ; 1.37)$ & $0.99(0.69 ; 1.42)$ \\
\hline
\end{tabular}

*Asthma defined as at least 1 case of 4 or more episodes of wheeze within the last 12 months, waking up in the night with shortness of breath, wheeze post-exercise or asthma diagnosed by doctor **Adjusted for gender, age, parental asthma, mother's education and cat at home. 
Table 5 Polytomous logistic regression analyses of associations between viral infections and asthma

\begin{tabular}{|c|c|c|c|c|c|}
\hline \multirow[t]{2}{*}{$N=1296$} & \multicolumn{2}{|c|}{$\begin{array}{c}\text { Non-atopic asthmatic } \\
N=154\end{array}$} & \multicolumn{3}{|c|}{$\begin{array}{l}\text { Atopic asthmatic } \\
\qquad \mathrm{N}=141\end{array}$} \\
\hline & n (\%) & OR $(C . I)^{*}$ & n (\%) & OR $(\mathrm{C} . \mathrm{I})^{*}$ & OR $(C . I)^{* *}$ \\
\hline \multicolumn{6}{|l|}{ HSV } \\
\hline No $(n=584)$ & $70(20.1)$ & 1 & $67(19.4)$ & 1 & 1 \\
\hline Yes $(n=712)$ & $84(18.3)$ & $0.96(0.66 ; 1.40)$ & $74(16.5)$ & $0.94(0.64 ; 1.38)$ & $1,15(0,76 ; 1,73)$ \\
\hline \multicolumn{6}{|l|}{ VZV } \\
\hline No $(n=708)$ & 86(19.8) & 1 & $77(18.1)$ & 1 & 1 \\
\hline Yes $(n=588)$ & $68(18.3)$ & $1.06(0.74 ; 1.54)$ & $64(17.4)$ & $1.04(0.71 ; 1.52)$ & $1,15(0,77 ; 1,74)$ \\
\hline \multicolumn{6}{|l|}{ EBV } \\
\hline No $(n=147)$ & 17(21.0) & 1 & $20(23.8)$ & 1 & 1 \\
\hline Yes $(n=1149)$ & 137(18.9) & $0.82(0.46 ; 1.48)$ & $121(17.0)$ & $0.64(0.37 ; 1.13)$ & $0,87(0,48 ; 1,57)$ \\
\hline \multicolumn{6}{|l|}{ HAV } \\
\hline No $(n=1072)$ & 124(18.7) & 1 & $121(18.3)$ & 1 & 1 \\
\hline Yes $(n=224)$ & $30(20.8)$ & $1.20(0.75 ; 1.92)$ & 20(14.9) & $0.83(0.49 ; 1.41)$ & $0,79(0,45 ; 1,39)$ \\
\hline
\end{tabular}

*Odds ratio for comparison with non-atopic non-asthmatics. Adjusted for gender, age, parental asthma, mother's education and cat at home.

** Odds ratio for comparison with atopic non-asthmatics. Adjusted for gender, age, parental asthma, mother's education and cat at home.

1) used by the hepatitis A virus to invade cells may be related to allergy $[27,28]$. Some studies have shown that $\mathrm{HAV}$ infection is negatively associated with allergic diseases $[11,20,29,30]$. This difference in findings in different geographic regions indicates that environmental and genetic factors may be influencing the ability of this virus to immunomodulate atopy and allergy or not.

In our study, there was no evidence that VZV infection was associated with the modulation of allergic responses or disease. However, Zhang and colleagues [31] and Janson and colleagues [12] showed that lymphocyte cultures stimulated with this virus could enhance the production of Th1 cytokines. Nilsson and colleagues [13] have also not find any association of this infection with atopy and allergic symptoms in children.

Although in this study EBV and HSV were inversely associated with SPTs, there was no association of these viral infections with specific IgEs against common allergens either using 0.35 or $0.70 \mathrm{kU} / \mathrm{L}$ as cut-offs. One possible explanation for these findings is that the presence of EBV, which had high prevalence $(88.9 \%)$ in our population, stimulated the production of IL-10, thereby preventing mast cell degranulation, even in the presence of IgE and thus decreasing SPT reactivity in children with elevated sIgEs. Another possible explanation is that our population, in contrast to affluent countries, is constantly infected and re-infected by helminths, which have been associated with elevated levels of IgE levels to aeroallergens due to possible cross-reactivity between parasite antigens and aeroallergens [18]. Possibly, as significant component of the specific IgE detected by Immunocap assays are in fact cross-reactive antibodies, which may not have enough affinity for the aeroallergen molecules and therefore do not crosslink in the FCeRII, a necessary step for the occurrence of mast cell degranulation.
The clinical diagnosis of asthma is difficult in preschool children. Most of the epidemiological studies use symptoms of asthma (wheezing in the last 12 months) or doctor's diagnosis of asthma as the indicators. In the current study we screened all children with a history of wheezing in the last 12 months with a few other questions aiming to increase the specificity of our criteria for asthma: diagnosis of asthma ever, wheezing with exercise; $\geq 4$ episodes wheezing, waking up night because of wheezing. They had to have at least one extra positive answer to the queries. Although we suppose our criteria are more accurate than the usual epidemiological definitions, we acknowledge the possibility some of the children we classified as having asthma may have transient wheezing. For that reason we made an analysis excluding children younger than 6 years, the only finding that differ from the previous analysis was the association of EBV infection with specifc IgE which was borderline in the whole children population analysis and became statistically significant but without differ the odds ratio in the analysis with children above 6 year old.

Many studies in the literature have shown negative associations between viral infections and asthma [12-14]; however, there was no strong evidence that the viral infections studied in our population mediate the development of asthma. Pearce and collaborators [32] showed that the positive association between SPTs and asthma is lower in developing countries than in developed countries. Given the large amount of non-atopic asthma found in the children studied herein [33], this may be a possible explanation for the absence an association between asthma and any of the studied viral infections. Furthermore, our data indicate the absence of association of the viral infection with asthma is not restricted to non-atopic asthma, but also to atopic asthma. 


\section{Conclusion}

Our data provide further evidence that common viral infections of childhood are associated with an attenuation of immediate hypersensitivity responses in children but not clinical disease. Given that most asthma is not associated with atopy in our study population, the data indicate that factors other than infection should be investigated as causing asthma in populations living in non-affluent countries.

\section{Study Limitation}

The current work is based solely on serology and does not take into account the age of infection or chronicity of infection. Another limitation is its inability to establish causality, since it is a cross-sectional analysis in which there is no information on the temporal sequence between exposure and outcome.

\section{Acknowledgements}

This study was conducted through the SCAALA (Social change, Asthma and Allergy in Latin America) initiative, funded by the Wellcome Trust, Grant No. 072405/Z/03/Z. The following funding agencies provided scholarships for the Brazilian authors: CAPES (RW and VCCD) CNPQ (AC, MLB and NMAN) The funding body did not participated in any step of the work.

\section{Author details}

'SCAALA (Social Change, Asthma and Allergy in Latin America) Research Program. ${ }^{2}$ Departamento de Ciências da Biointeração, Instituto de Ciências da Saúde, Universidade Federal da Bahia, Av. Reitor Miguel Calmon, Canela, Salvador, CEP 40110100, Brazil. Departamento de Medicina Social, Centro de Ciências da Saúde, Universidade Federal de Pernambuco, Av. Prof. Moraes Rêgo, 1235, Cidade Universitária, Recife, CEP 50670-901, Brazil. ${ }^{4}$ ProAR, Departamento de Clínica Médica, Faculdade de Medicina da Bahia, Universidade Federal da Bahia, Av. Reitor Miguel Calmon, Canela, Salvador, CEP 40110100, Brazil. ${ }^{5}$ Colegio de Ciencias de la Salud, Universidad San Franscisco de Quito, Hospital de Los Valles, Via Interoceanica Km 12.5, Quito, Ecuador. ${ }^{6}$ Molecular and Biochemical Parasitology, Liverpool School of Tropical Medicine, Pembroke Place, Liverpool L3 5QA, UK. ${ }^{7}$ London School of Hygiene and Tropical Medicine, Keppel Street, London WC1E 7HT, UK. ${ }^{8}$ Instituto de Saúde Coletiva, Universidade Federal da Bahia, Rua Basílio da Gama S/N Canela, Salvador, CEP 40.110-040, Brazil.

\section{Authors' contributions}

RW-carried out the laboratory assays and the statistical analysis and drafted the text. SC- Supervised the field work and the statistical analysis; VCCD carried out the laboratory work; AC, PJC and LCR - helped in the work design and reviewed the manuscript; MLB - coordinated the SCAALA project, helped in the work design. NMAN - designed the work, coordinated the laboratory work and reviewed the text. All authors have read and approved the final manuscript.

\section{Competing interests}

The authors declare that they have no competing interests.

Received: 2 June 2010 Accepted: 14 May 2011 Published: 14 May 2011

\section{References}

1. Worldwide variation in prevalence of symptoms of asthma, allergic rhinoconjunctivitis, and atopic eczema: ISAAC. The International Study of Asthma and Allergies in Childhood (ISAAC) Steering Committee. Lancet 1998, 351(9111):1225-1232

2. Marks GB: Environmental factors and gene-environment interactions in the aetiology of asthma. Clin Exp Pharmacol Physiol 2006, 33(3):285-289.
3. Strachan DP: Hay fever, hygiene, and household size. BMJ 1989, 299(6710):1259-1260.

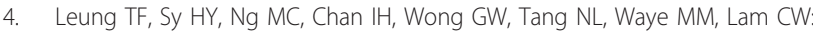
Asthma and atopy are associated with chromosome 17q21 markers in Chinese children. Allergy 2009, 64(4):621-628.

5. Daniels SE, Bhattacharrya S, James A, Leaves NI, Young A, Hill MR, Faux JA, Ryan GF, le Souef PN, Lathrop GM, et al: A genome-wide search for quantitative trait loci underlying asthma. Nature 1996, 383(6597):247-250.

6. Nicolai T, Pereszlenyiova-Bliznakova L, Illi S, Reinhardt D, von Mutius E: Longitudinal follow-up of the changing gender ratio in asthma from childhood to adulthood: role of delayed manifestation in girls. Pediatr Allergy Immunol 2003, 14(4):280-283.

7. Celedon JC, Wright RJ, Litonjua AA, Sredl D, Ryan L, Weiss ST, Gold DR: Day care attendance in early life, maternal history of asthma, and asthma at the age of 6 years. Am J Respir Crit Care Med 2003, 167(9):1239-1243.

8. Chen JT, Krieger N, Van Den Eeden SK, Quesenberry CP: Different slopes for different folks: socioeconomic and racial/ethnic disparities in asthma and hay fever among 173,859 U.S. men and women. Environ Health Perspect 2002, 110(Suppl 2):211-216.

9. Ngoc PL, Gold DR, Tzianabos AO, Weiss ST, Celedon JC: Cytokines, allergy, and asthma. Curr Opin Allergy Clin Immunol 2005, 5(2):161-166.

10. Renz H, Herz U: The bidirectional capacity of bacterial antigens to modulate allergy and asthma. Eur Respir J 2002, 19(1):158-171.

11. Cullinan P, Harris JM, Newman Taylor AJ, Jones M, Taylor P, Dave JR, Mills P, Moffat SA, White CW, Figg JK, et al: Can early infection explain the sibling effect in adult atopy? Eur Respir J 2003, 22(6):956-961.

12. Janson C, Asbjornsdottir $H$, Birgisdottir A, Sigurjonsdottir RB, Gunnbjornsdottir M, Gislason D, Olafsson I, Cook E, Jogi R, Gislason T, et al: The effect of infectious burden on the prevalence of atopy and respiratory allergies in Iceland, Estonia, and Sweden. J Allergy Clin Immunol 2007, 120(3):673-679.

13. Nilsson C, Linde A, Montgomery SM, Gustafsson L, Nasman P, Blomberg MT, Lilja G: Does early EBV infection protect against lgE sensitization? J Allergy Clin Immunol 2005, 116(2):438-444.

14. Illi S, von Mutius E, Lau S, Bergmann R, Niggemann B, Sommerfeld C, Wahn U: Early childhood infectious diseases and the development of asthma up to school age: a birth cohort study. BMJ 2001, 322(7283):390-395.

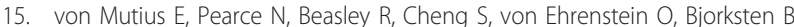
Weiland S: International patterns of tuberculosis and the prevalence of symptoms of asthma, rhinitis, and eczema. Thorax 2000, 55(6):449-453.

16. Sole D, Wandalsen GF, Camelo-Nunes IC, Naspitz CK: Prevalence of symptoms of asthma, rhinitis, and atopic eczema among Brazilian children and adolescents identified by the International Study of Asthma and Allergies in Childhood (ISAAC) - Phase 3. J Pediatr (Rio J) 2006, 82(5):341-346.

17. Barreto ML, Cunha SS, Alcantara-Neves N, Carvalho LP, Cruz AA, Stein RT, Genser B, Cooper PJ, Rodrigues LC: Risk factors and immunological pathways for asthma and other allergic diseases in children: background and methodology of a longitudinal study in a large urban center in Northeastern Brazil (Salvador-SCAALA study). BMC Pulm Med 2006, 6:15

18. Santos AB, Rocha GM, Oliver C, Ferriani VP, Lima RC, Palma MS, Sales VS, Aalberse RC, Chapman MD, Arruda LK: Cross-reactive lgE antibody responses to tropomyosins from Ascaris lumbricoides and cockroach. J Allergy Clin Immunol 2008, 121(4):1040-1046 e1041.

19. Lundberg $P$, Welander $P$, Han $X$, Cantin E: Herpes simplex virus type 1 DNA is immunostimulatory in vitro and in vivo. J Virol 2003, 77(20):11158-11169.

20. Matricardi PM, Rosmini F, Panetta V, Ferrigno L, Bonini S: Hay fever and asthma in relation to markers of infection in the United States. J Allergy Clin Immunol 2002, 110(3):381-387.

21. Wingate PJ, McAulay KA, Anthony IC, Crawford DH: Regulatory T cell activity in primary and persistent Epstein-Barr virus infection. J Med Virol 2009, 81(5):870-877.

22. Marshall NA, Culligan DJ, Johnston PW, Millar C, Barker RN, Vickers MA: CD4 (+) T-cell responses to Epstein-Barr virus (EBV) latent membrane protein 1 in infectious mononucleosis and EBV-associated non-Hodgkin lymphoma: Th1 in active disease but $\operatorname{Tr} 1$ in remission. $\mathrm{Br} J$ Haematol 2007, 139(1):81-89.

23. Raftery MJ, Wieland D, Gronewald S, Kraus AA, Giese T, Schonrich G: Shaping phenotype, function, and survival of dendritic cells by cytomegalovirus-encoded IL-10. J Immunol 2004, 173(5):3383-3391. 
24. Nilsson C, Larsson Sigfrinius AK, Montgomery SM, Sverremark-Ekstrom E, Linde A, Lilja G, Blomberg MT: Epstein-Barr virus and cytomegalovirus are differentially associated with numbers of cytokine-producing cells and early atopy. Clin Exp Allergy 2009, 39(4):509-517.

25. Uter W, Stock C, Pfahlberg A, Guillen-Grima F, Aguinaga-Ontoso I, BrunSandiumenge C, Kramer A: Association between infections and signs and symptoms of 'atopic' hypersensitivity-results of a cross-sectional survey among first-year university students in Germany and Spain. Allergy 2003, 58(7):580-584

26. Gonzalez-Quintela A, Gude F, Boquete O, Aguilera A, Rey J, Meijide LM, Fernandez-Merino MC, Vidal C: Association of hepatitis A virus infection with allergic sensitization in a population with high prevalence of hepatitis A virus exposure. Allergy 2005, 60(1):98-103.

27. McIntire JJ, Umetsu SE, Macaubas C, Hoyte EG, Cinnioglu C, CavalliSforza LL, Barsh GS, Hallmayer JF, Underhill PA, Risch NJ, et al: Immunology: hepatitis A virus link to atopic disease. Nature 2003, 425(6958):576.

28. Xu G, Cheng L, Lu L, Zhu Y, Xu R, Yao X, Li H: Expression of T-cell immunoglobulin- and mucin-domain-containing molecule-1 (TIM-1) is increased in a mouse model of asthma and relationship to GATA-3. Life Sci 2008, 82(11-12):663-669.

29. Matricardi PM: Infections preventing atopy: facts and new questions. Allergy 1997, 52(9):879-882.

30. Matricardi PM, Rosmini F, Riondino S, Fortini M, Ferrigno L, Rapicetta M, Bonini S: Exposure to foodborne and orofecal microbes versus airborne viruses in relation to atopy and allergic asthma: epidemiological study. BMJ 2000, 320(7232):412-417.

31. Zhang Y, Cosyns M, Levin MJ, Hayward AR: Cytokine production in varicella zoster virus-stimulated limiting dilution lymphocyte cultures. Clin Exp Immunol 1994, 98(1):128-133.

32. Pearce $N$, Pekkanen $J$, Beasley R: How much asthma is really attributable to atopy? Thorax 1999, 54(3):268-272.

33. Cunha SS, Barreto ML, Fiaccone RL, Cooper PJ, Alcantara-Neves NM, Simões SM, Cruz AA, Rodrigues LC: Asthma cases in childhood attributed to atopy in tropical area in Brazil. Revista Panamericana de Salud Pública 2010, 28:405-411.

\section{Pre-publication history}

The pre-publication history for this paper can be accessed here: http://www.biomedcentral.com/1471-2466/11/24/prepub

doi:10.1186/1471-2466-11-24

Cite this article as: Veiga et al:: Chronic virus infections supress atopy but not asthma in a set of children from a large latin american city: a cross-section study. BMC Pulmonary Medicine 2011 11:24.

\section{Submit your next manuscript to BioMed Central and take full advantage of:}

- Convenient online submission

- Thorough peer review

- No space constraints or color figure charges

- Immediate publication on acceptance

- Inclusion in PubMed, CAS, Scopus and Google Scholar

- Research which is freely available for redistribution

Submit your manuscript at www.biomedcentral.com/submit
Biomed Central 